\title{
Morphological and ultrastructural analysis of the teeth of guaiquica (Gracilinanus microtarsus, Wagner, 1842)
}

\author{
LOBO, L. M. ${ }^{1 *}$, SANTOS, A. C. ${ }^{1}$, ROSA, R. A. ${ }^{2}$, CARVALHO, A. F. ${ }^{2}$, COSTA, \\ G. M. ${ }^{3}$ and MANÇANARES, C. A. F. ${ }^{2}$
}

\author{
${ }^{1}$ Sector of Anatomy of Domestic and Wild Animals, Department of Surgery, School of Veterinary Medicine and \\ Animal Science, Universidade de São Paulo - USP, Av. Prof. Dr. Orlando Marques de Paiva, 87, CEP 05508-270, \\ São Paulo, SP, Brazil \\ ${ }^{2}$ Laboratory of Morphological Science, Centro Universitário Fundação de Ensino Octávio Bastos - UNIFEOB, \\ Parque dos Jequitibás, CEP 13874-159, São João da Boa Vista, SP, Brazil \\ ${ }^{3}$ Universidade do Estado de Mato Grosso - UNEMAT, Av. Perimetral Rogério Silva, s/n, Flamboyant, \\ CEP 78580-000, Alta Floresta, MT, Brazil \\ *E-mail: miguel_simons@hotmail.com
}

\begin{abstract}
Introduction: The guaiquica (Gracilinanus microtarsus) is an omnivorous-frugivorous marsupial, which belongs to family Didelphidae and subfamily Didelphinae. By feeding on small fruits, it is a species of considerable ecological importance in seed dispersal of some plants. The teeth are calcified and have adapted anatomical structures, which exhibit morphological variation among vertebrates. They are important for the systematic and sometimes represent the only traces of extinct species, and may also assist the phylogenetic reconstruction of these species. Objective: In order to establish morphological patterns of the teeth of G. microtarsus, the establishment of dental formula of the species was performed. Materials and methods: We used macroscopic analysis, microstructural analysis by light microscopy and ultrastructural analysis by scanning electron microscopy in five $G$. microtarsus adults ( $\mathrm{n}=3$ males and $\mathrm{n}=2$ females) were performed. Results and conclusion: We conclude that the dental formula of $G$. microtarsus $(2 \times \mathrm{I} 5 / 4 \mathrm{Cl} / 1 \mathrm{P} 3 / 3 \mathrm{M} \mathrm{4} / 4$ ), totaling 50 teeth is similar to that described in opossum (Didelphis sp.). The teeth are classified as thecodont and bunodont and microscopic morphology of teeth is also similar to Didelphis sp. and other species that have braquidonts teeth.
\end{abstract}

Keywords: didelphidae, digestory apparatus, marsupials, oral cavity.

\section{Introduction}

The guaiquica (Gracilinanus microtarsus), also known in Brazil as guaiquiquinha and catita are marsupials, which belongs to family Didelphidae and subfamily Didelphinae (LIMA, SANTOS, VIANA et al., 2013; LOBO, SANTOS, ROSA et al., 2014). This species presents white hairs at the ventral region and brown and gray hairs at the lateral and dorsal regions of body; black rounded spots around the eyes and small rounded ears; tapering and small snout and prehensile and hairless tail. It measures between 18 and $22 \mathrm{~cm}$ of length from snout to tail (CÁCERES, CASELLA, VARGAS et al., 2008).

It has omnivorous-frugivorous habits with varied diet consisting of insects, fruits and small vertebrates. By feeding on small fruits, it is a species of considerable ecological importance in seed dispersal of some plants (LOBO, SANTOS, ROSA et al., 2014), because it can moving long distances in the forests, then spreads together with their feces, the seeds of the fruits that ingests (FONTES, PASSAMANI, JACINTO et al., 2007).

Members of our research group have searched morphological correlations in organs of the digestive tract between different species of mammals such as the procyonidae Nasua nasua (SANTOS, BERTASSOLI, OLIVEIRA et al., 2010, 2012; SOUZA, OLIVEIRA, SANTOS et al., 2012) and Procyon cancrivorus (SANTOS, BERTASSOLI, OLIVEIRA et al., 2012; SANTOS, OLIVEIRA, VIANA ET AL., 2013); marsupials as Didelphis marsupialis (CARVALHO, MANÇANARES, CASALS 2004; MANÇANARES, SANTOS, PIEMONTE et al., 2012); rodents as Kerodon rupestris (THOMAZ, CARVALHO, MIGLINO et al., 2006; SANTOS, ARO, BERTASSOLI et al., 2015); and between primates Callithrix jacchus, C. penicillata and C. geoffroyi (BERTASSOLI, SILVA, OLIVEIRA et al., 2013). Then, these morphological studies have been useful in phylogenetic comparison between species of different taxa.

The teeth are calcified and have adapted anatomical structures to collect, retain, cut, drill, tearing, crushing, grinding or milling the foods. They also have functions of attack, defense, movement and sexual courtship (BERTASSOLI, SILVA, OLIVEIRA et al., 2013). They are adaptable according to the feed habits of animals, and exhibit morphological variation among vertebrates. They are important for the systematic, because have permanent structure within the taxa (HILDEBRAND, 1995). Because teeth are hard and mineralized tissues, sometimes represent the only traces of extinct species, and may also assist the phylogenetic reconstruction of these species (DELLA-SERRA and FERREIRA, 1981).

In order to establish morphological patterns of the teeth of G. microtarsus, the establishment of dental formula of the species using macroscopic analysis, microstructural analysis 
by light microscopy and ultrastructural analysis by scanning electron microscopy were performed.

\section{Materials and Methods}

\subsection{Animals}

Five G. microtarsus adults were used $(\mathrm{n}=3$ males and $\mathrm{n}=2$ females). The animals were fixed in $10 \%$ formaldehyde solution and kept in 70\% ethanol solution. All animals were provided by Laboratory of Morphological Sciences at University Center of the Education Foundation Octávio Bastos with authorization from IBAMA (02001.007176/03-69).

\subsection{Macroscopic and topographic analysis}

The jaws of the animals were displaced to observation, description and counting of maxillary and mandibular teeth. The teeth were photographed with camera Sony Mavica $3.2 \mathrm{mp}$. Then the teeth were removed for light and scanning electron microscopy (SEM) analysis.

\subsection{Light microscopy}

Molars, premolars, canines and incisors were processed by abrasive technique and observed under an optical microscope. Other samples were subjected to decalcification technique with a solution containing $800 \mathrm{~mL}$ of distilled water, $120 \mathrm{~mL}$ of formic acid and $80 \mathrm{~mL}$ of hydrochloric acid. After chemical decalcification materials were processed by routine technique of inclusion in paraffin. Then the material was cut into microtome Leica RM2165. $5 \mathrm{~mm}$ thick sections were stained with Hematoxilin/Eosin (HE). Photodocumentation was performed by light microscope Nikon E-400.

\subsection{Scanning Electron Microscopy (SEM)}

Samples of each tooth were dehydrated in ethanol at increasing concentration 50-100\% and critical point Balzers CPD 020. Tissue fragments were fixed on metal supports (stubs) and then coated with gold ("sputtering" Emitech $\mathrm{K} 550$ ). The analysis was performed by Electron Microscope Leo 435 VP.

\section{Results}

\subsection{Macroscopic analysis and dental formula}

The teeth have a portion embedded in the bone and an exposed part above of the gingiva. Ten maxillary incisors (I) and eight mandibular incisors were found. Diastema between the maxillary frontal incisors and lateral incisors and diastema between right and left mandibular lateral incisors were found $(\mathrm{n}=18 \mathrm{I})$. Two mandibular and two maxillary canines $(C)(n=4 C)$ with diastema between them and the first premolars $(\mathrm{P})$ were found. Six mandibular and six maxillary premolars $(\mathrm{n}=12 \mathrm{P})$ with diastema between the first and second premolars and eight maxillary and eight mandibular molars $(\mathrm{M})(\mathrm{n}=16 \mathrm{M})$ also were found (Figure 1). The dental formula was classified as 2x I $5 / 4 \mathrm{Cl} / 1 \mathrm{P} 3 / 3 \mathrm{M} \mathrm{4} / 4$, totaling 50 teeth.

\subsection{Light microscopy}

The teeth were classified as braquidontes-type, in which the crown was covered by enamel above of the gingiva. The roots were inserted into the alveolar bone, united by periodontal ligament. Have layers of enamel, dentin with tubules and cementum and have crown and root with radicular channel.
The cement presented the cementocytes. The pulp was formed by blood vessels and nerves inside the loose connective tissue (Figures 2, 3)

\subsection{Scanning electron microscopy}

Two frontal maxillary incisors were found arranged next to the lip fissure and had a diastema between them and the lateral incisors, which had acute cusps with straight apex. The canine teeth had conical shape with more acute cusps those incisors. The premolars had less acute conical cusps that the canine teeth, but more acute than cusps of the incisors. The molar teeth had several cusps, which showed differences between the maxillary and mandibular teeth (Figure 4). On the molars was possible to observe the cusps, the roots, the crown, pulp, dentin, cementum and enamel (Figure 5).

\section{Discussion}

The absolute and relative dimensions of each tooth vary according to species. In individual animals teeth can vary according to age, level of specialization, vital occurrence and dimorphism. Simpler and more numerous teeth are found
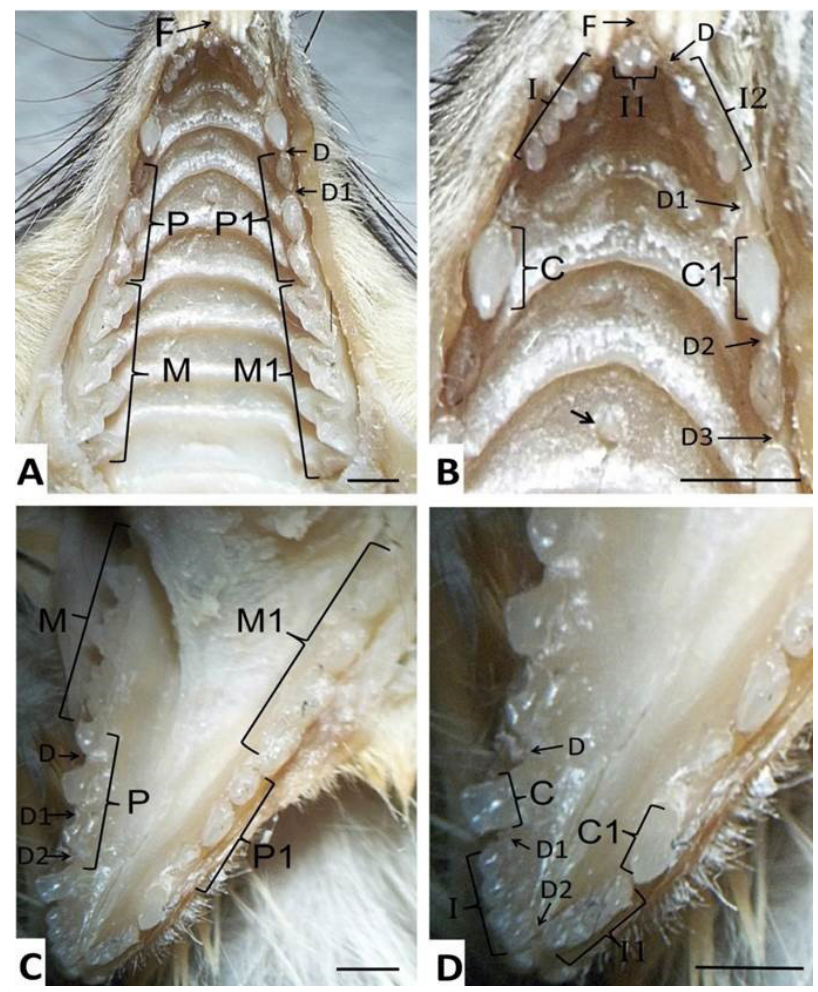

Figure 1. Maxillary $(\mathrm{AB})$ and mandibular $(\mathrm{CD})$ teeth of the G. microtarsus. (A) frontal incisors (F); premolars (P-Pl); molars (M-Ml); diastema between canine and first premolar (D) and between first and second premolar (Dl). (B) lip fissure (F); diastema (D) between frontal (I1) and lateral incisors (I-I2); diastema (DI) between the lateral incisors (I-I2) and canine (C-Cl); diastema (D2) between canine (C-Cl) and first premolar; diastema between the first and second premolar (D3). (C) molar (M-Ml); premolars (P-P1); diastema between canine and first premolar (D2) and between the first and second premolar (Dl). (D) diastema (D) between canine and first premolars; diastema (Dl) between lateral incisors (I-I1) and canine (C-Cl) and diastema (D2) between the lateral incisors. Bars: $5 \mathrm{~mm}$. 


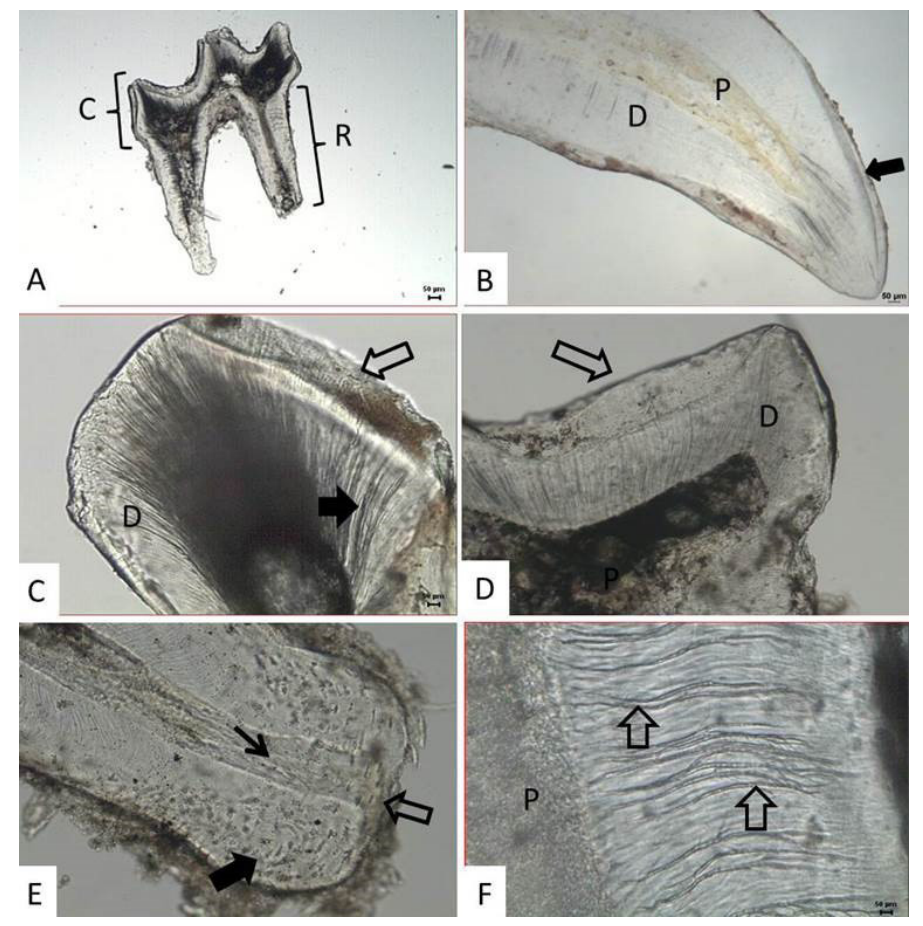

Figure 2. Photomicrograph of the teeth of G. microtarsus. (A) crown (C) and root (R) of the maxillary premolar. (B) Enamel (arrow); pulp (P); dentin (D) of the maxillary canine. (C) dentin tubules (full arrow); cementum (empty arrows) and dentin (D). (D) dentin (D) tubules (arrow) and molar pulp (P). (E) radicular channel (arrow); cementum (full arrow) and periodontal ligament (empty arrow) of the maxillary incisor. $(\mathbf{F})$ pulp (P) and dentin tubules (arrows) of the maxillary incisor. Bars: $50 \mu \mathrm{m}$. Abrasive technique.

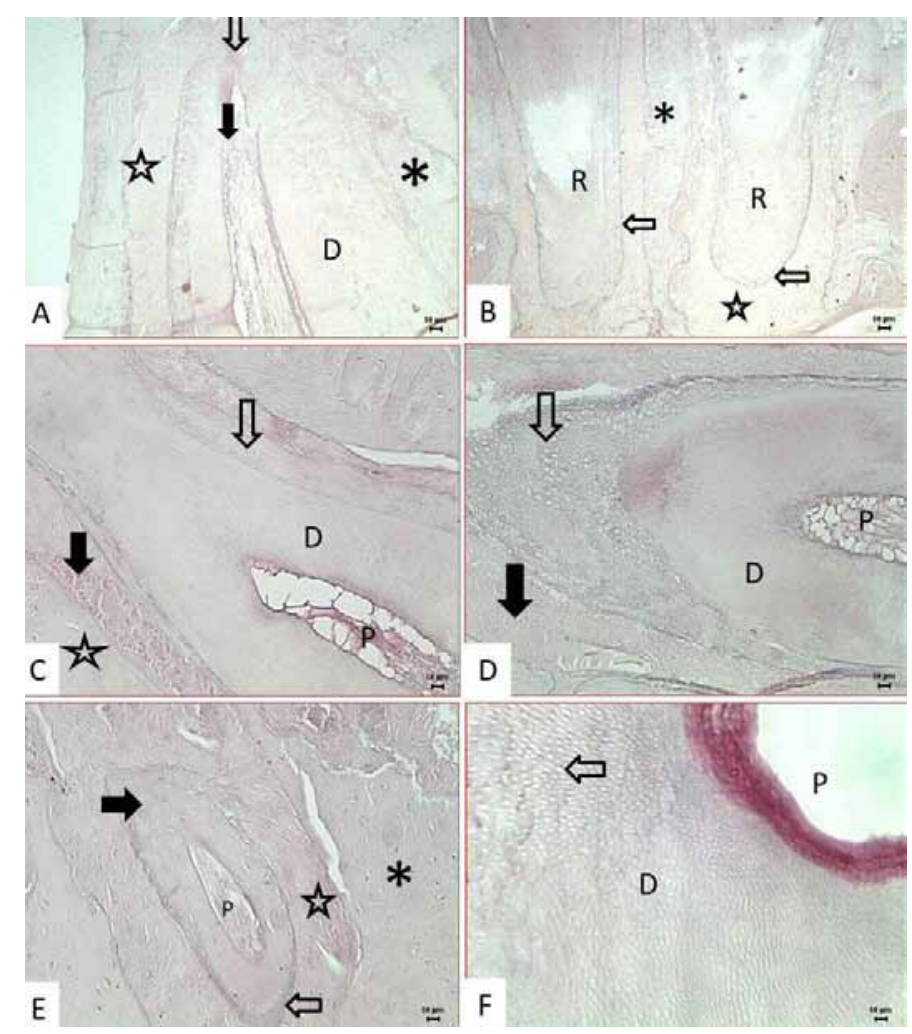

Figure 3. Photomicrograph of the teeth of G. microtarsus. (A) apical foramen (arrow); root canal (filled arrow) of the periodontal ligament (star); alveolar bone $\left({ }^{*}\right)$ and dentin of the maxillary canine. (B) roots ( $\left.\mathrm{R}\right)$; cement (arrows); periodontal ligament (star); alveolar bone (*) of the mandibular premolar. C: pulp (P); dentin (D); cementum (arrow), periodontal ligament (full arrow); alveolar bone (star) of the maxillary premolar. (D) cement (arrow); periodontal ligament (full arrow); pulp (P); dentin (D) of the mandibular canine. (E) cement (arrow); dentin (filled arrow); pulp (P); periodontal ligament (star); alveolar bone $\left({ }^{*}\right)$ of the maxillary incisor. (F) pulp (P); dentin (D) and dentin tubules of the maxillary molar. Bars: $50 \mu \mathrm{m}$. Decalcification technique. HE staining. 
in less phylogenetically complex animals while fewer and more complex teeth are found in more complex animals (DELLA-SERRA and FERREIRA, 1981). The change in the number of teeth in mammals is an adopted strategy to develop more specialized dentition, an important factor in the diversification of species (LINE, 2003).
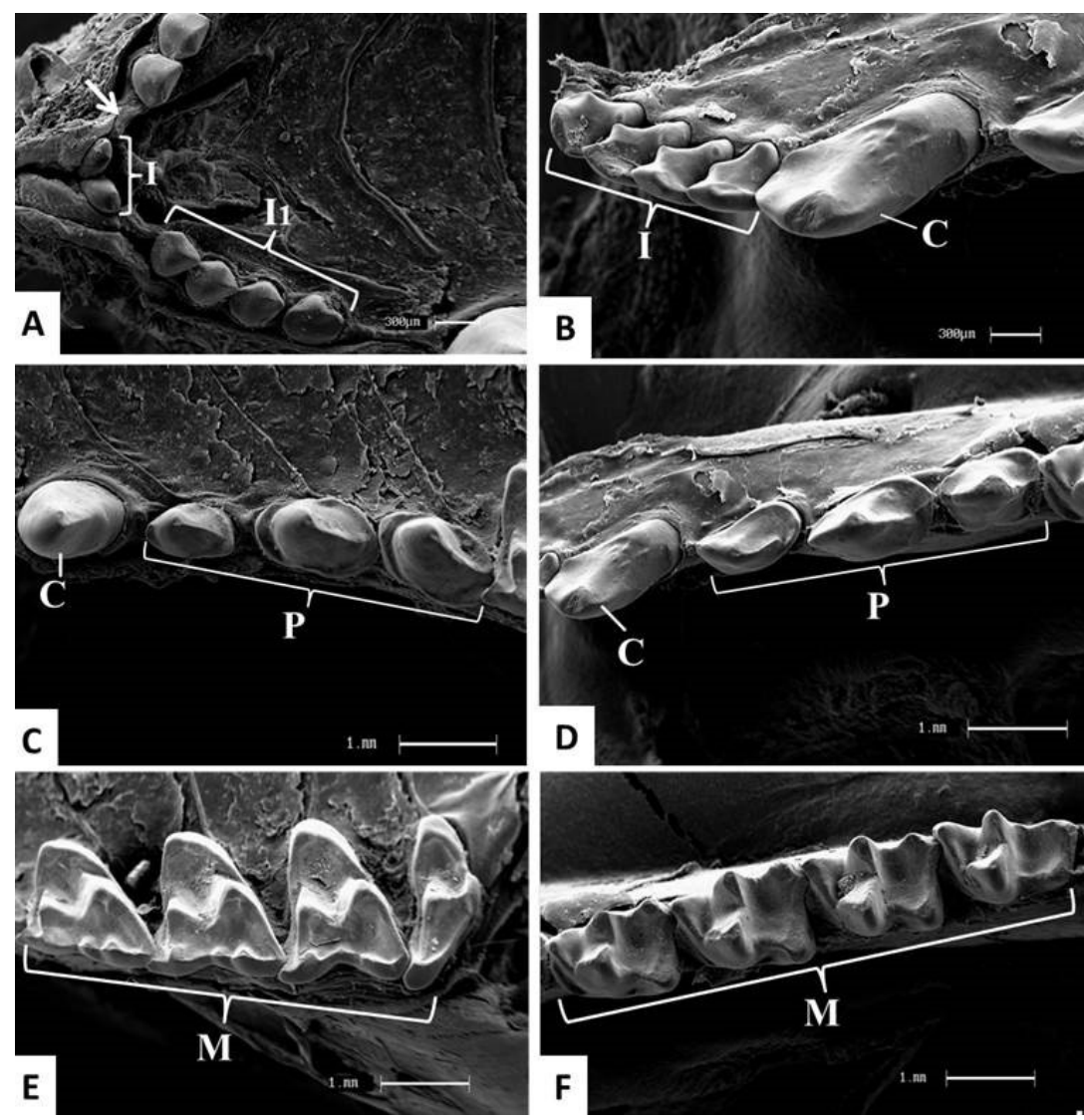

Figure 4. Electromicrographs of the teeth of G. microtarsus. (A) frontal maxillary incisors (I); diastema (arrow) and lateral incisors (I1). (B) mandibular lateral incisors (I) and canine (C). Bars: $300 \mu \mathrm{m}$. (C) maxillary canine (C) and premolars (P). (D) mandibular canine $(\mathrm{C})$ and premolars $(\mathrm{P})$. (E) maxillary molars $(\mathrm{M})$. (F) mandibular molars $(\mathrm{M})$. Bars: $\mathrm{Imm}$.
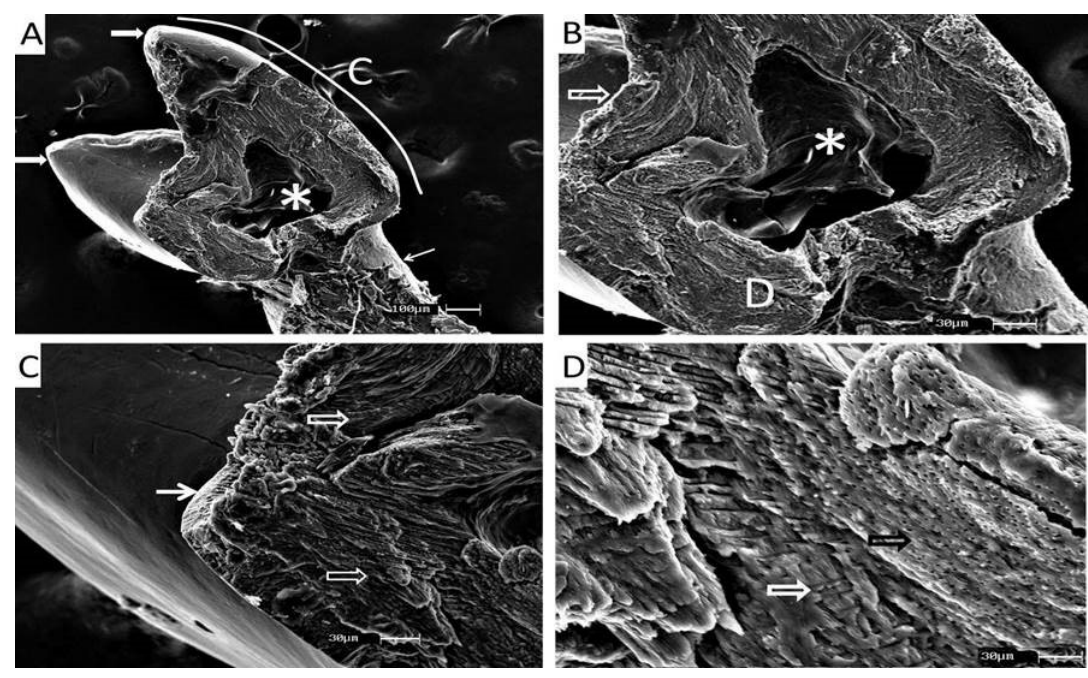

Figure 5. Electromicrographs of the molar teeth of G. microtarsus. (A) cusps (full arrow); crown (C); root (arrow); pulp (*). Bar: $100 \mu \mathrm{m}$. (B) Enamel (arrow); dentin (D); pulp (*). (C) enamel (arrow); dentin (empty arrows). (D) dentin (black arrow); cement (white arrow). Bars: $30 \mu \mathrm{m}$. 
and Nasua nasua (PIERI, MANÇANARES, BERTASSOLI et al., 2011). Present species has the dental formula $2 \mathrm{x} \mathrm{I} 5 / 4 \mathrm{Cl} / 1$ P $3 / 3 \mathrm{M} \mathrm{4} / 4$, similar that found in Didelphis marsupialis, which also belong to the family Didelphidae (CARVALHO, MANÇANARES, CASALS et al., 2004).

In another study, members of our research group found similarity in the dental formula of Callithrix jacchus, C. penicillata and C. geoffroyi, and both species belong to the family Callitrichidae. In these three species dental formula was 2 x I 2/2, C 1/1, PM 3/3, M 2/2, totaling 32 teeth (BERTASSOLI, SILVA, OLIVEIRA et al., 2013). Rodents as Kerodon rupestris (THOMAZ, CARVALHO, MIGLINO et al., 2006) and Chinchilla lanigera (CROSSLEY, JACKSON, YATES et al., 1998) also have the same dental formula 2x I $1 / 1, \mathrm{C} 0 / 0, \mathrm{P} 1 / 1, \mathrm{M} 3 / 3$, showing the importance of teeth in the systematic (HILDEBRAND, 1995).

Microscopically, the G. microtarsus have braquidont teeth composed of enamel, dentin, pre-dentin, pulp and periodontium as described in Didelphis marsupialis (CARVALHO, MANÇANARES, CASALS et al., 2004) and Callitrichidae (BERTASSOLI, SILVA, OLIVEIRA et al., 2013). After their formation, do not have continuous growth throughout life (BANKS, 1991). In Didelphidae, the teeth eruption sequence is similar in most species (TRIBE, 1990). The Didelphis albiventris have the onset of dentinogenesis around the third week after birth. The enamel begins to appear at this stage and will be deposited until the tenth week, and from that stage starts the maturation period (AZEVEDO and GOLDBERG, 1987). This process of formation, growth and eruption of teeth is influenced by several factors such as growth hormone, adrenal hormones, sex etc. (SASSAKI, DELBEM, SANTOS et al., 2003).

In G. microtarsus, similar to that described in D. marsupialis, the internal epithelium of enamel is composed of ameloblasts (columnar cells). The external epithelium of enamel is formed by small flattened cells. The pulp is formed by many blood vessels and nerves inside the loose connective tissue (CARVALHO, MANÇANARES, CASALS et al., 2004).

We conclude that the dental formula of $G$. microtarsus (2x I $5 / 4 \mathrm{Cl} / 1 \mathrm{P} 3 / 3 \mathrm{M} 4 / 4)$ is similar to that described in opossum (Didelphis sp.); the teeth are classified as thecodont and bunodont; microscopic morphology of teeth is also similar to Didelphissp. and other species that have braquidonts teeth.

Acknowledgements: This work was supported by a grant from Fundação de Amparo a Pesquisa do Estado de São Paulo- FAPESP.

\section{References}

AZEVEDO, N. and GOLDBERG, M. Post-natal development of tooth structures in Didelphis albiventris. Journal de Biologie Buccale, 1987, vol. 15, n. 1, p. 23-35. PMid:2435710.

BANKS, WJ. Histologia veterinária aplicada. 2nd ed. São Paulo: Manole, 1991. 629 p.

BERTASSOLI, BM., SILVA, LCS., OLIVEIRA, FD., SANTOS, AC., MANÇANARES, CAF. and ASSIS NETO, AC. Classificação morfofuncional dos dentes de saguis-de-tufo-branco (Callithrix jacchus, Callitrichidae), saguis-de-tufo-preto (C. penicillata) e saguisde-cara-branca (C.geoffroyi). Acta Amazonica, 2013, vol. 43, n. 3, p. 377-382. http://dx.doi.org/10.1590/S0044-59672013000300014.

CÁCERES, NC., CASElla, J., VARGAS, CF., PRATES, LZ., TOMBINI, AAM., GOULART, CS. and LOPES, WH. Distribuição geográfica de pequenos mamíferos não-voadores nas bacias dos rios Araguaia e Paraná, região Centro-Sul do Brasil. Iheringia, 2008, vol. 98 , n. 2, p. 173-180.

CARVALHO, AF., MANÇANARES, CF., CASALS, J., THOMAZ, JM., BELLATINE, T., MIGLINO, MA., AMBRÓSIO, CE., ESTEVES, A., ROQUETO, MA. and ROSA, RA. Análise macro e microscópica do dente do gambá (Didelphissp.). In Anais do V Encontro de Produção Acadêmica do Curso de Medicina Veterinária, 2004. São João da Boa Vista: Unifeob, 2004. p. 155-158. vol. 5.

CROSSLEY, DA., JACKSON, A., YATES, J. and BOYDELL, IP. Use of computed tomography to investigate cheek tooth abnormalities in chinchillas (Chinchilla laniger). The Journal of Small Animal Practice, 1998, vol. 39, n. 8, p. 385-389. http://dx.doi. org/10.1111/j.1748-5827.1998.tb03737.x. PMid:9741874.

DELLA-SERRA, O. and FERREIRA, FV. Dente pré-molares. In DELLA SERRA, O. and FERREIRA, FV. (Eds.). Anatomia dental. 3rd ed. São Paulo: Artes Médicas, 1981. p. 101-121.

FONTES, SV., PASSAMANI, M., JACINTO, CH., PEREIRA, MS. and SANT'ANA, APP. Área de vida e deslocamento de Akodon montensis e Gracilinanus microtarsus em um fragmento no sul de Minas Gerais. In Anais do VIII Congresso de Ecologia do Brasil, 2007. Caxambu: Sociedade de Ecologia do Brasil, 2007. p. 1-2. vol. 8.

HILDEBRAND, M. Análise da estrutura dos vertebrados. São Paulo: Atheneu, 1995.700 p.

LIMA, JMN., SANTOS, AC., VIANA, DC., BERTASSOLI, BM., LOBO, LM., OLIVEIRA, VC., BRIANI, DC., COSTA, GM., ASSIS-NETO, AC., AMBRÓSIO, CE., CARVALHO, AF. and MANÇANARES, CAF. Morphological study of the male genital organs of Gracilinanus microtarsus. Brazilian Journal of Veterinary Research and Animal Science, 2013, vol. 50, n. 6, p. 447-456. http://dx.doi. org/10.11606/issn.1678-4456.v50i6p447-456.

LINE, SR. Variation of tooth number in mammalian dentition: connecting genetics, development, and evolucion. Evolution \& Development, 2003, vol. 5, n. 3, p. 295-304. http://dx.doi.org/10.1046/j.1525142X.2003.03036.x. PMid:12752768.

LOBO, LM., SANTOS, AC., ROSA, RA., AMBRÓSIO, CE., BRIANE, DC., COSTA, GM., CARVALHO, AF. and MANÇANARES, CAF. Estudo macroscópico do aparelho digestório de Gracilinanus microtarsus (Wagner, 1842) (Mammalia: Didelphidae). Biotemas, 2014, vol. 27, n. 1, p. 109-120.

MANÇANARES, CAF., SANTOS, AC., PIEMONTE, MV., VASCONCELOS, BG., CARVALHO, AF., MIGLINO, MA., AMBRÓSIO, CE. and ASSIS-NETO, AC. Macroscopic and microscopic analysis of the tongue of the common opossum (Didelphis marsupialis). Microscopy Research and Technique, 2012, vol. 75, n. 3, p. 1329-1333. http://dx.doi.org/10.1002/jemt.22070. PMid:22581756.

PIERI, NCG., MANÇANARES, CAF., BERTASSOLI, BM., LIMA, JMN., THOMAZ, JM. and CARVALHO, AF. Classificação morfofuncional dos dentes de quati, Nasua nasua. Pesquisa Veterinaria Brasileira, 2011, vol. 31, n. 5, p. 447-451.

SANTOS, AC., BERTASSOLI, BM., OLIVEIRA, VC., ROSA, RA., CARVALHO, AF. and MANÇANARES, CAF. Caracterização morfológica das glândulas salivares mandibulares dos quatis (Nasua nasua, Linnaeus, 1758). Revista da FZVA, 2010, vol. 17, n. 2, p. 276-286.

SANTOS, AC., BERTASSOLI, BM., OLIVEIRA, FD., OLIVEIRA, DM., OLIVEIRA, VC., VASCONCELOS, BG., CARVALHO, AF., MANÇANARES, ACF. and ASSIS-NETO AC. Estrutura macro e microscópica das glândulas salivares parótidas em duas espécies de procionídeos: mão-pelada (Procyon cancrivorus, G. Cuvier, 1798) e quati (Nasua nasua, Linnaeus, 1766). Biotemas, 2012, vol. 25, n. 1, p. 93-101. 
SANTOS, AC., OLIVEIRA, VC., VIANA, DC., LOBO, LM., AMBRÓSIO, CE., ASSIS-NETO, AC., CARVALHO, AF. and MANÇANARES, CAF. Análise microscópica e ultraestrutural das glândulas salivares mandibulares de Procyon cancrivorus. Pesquisa Veterinária Brasileira, 2013, vol. 33, suplemento 1, p. 39-44.

SANTOS, AC., ARO, MM., BERTASSOLI, BM., VIANA, DC., VASCONCELOS, BG., RICI, REG., OLIVEIRA, MF., MIGLINO, MA. and ASSIS-NETO, AC. Morphological characteristics of the tongue of the rock cavy- Kerodon rupestris Wied, 1820 (Rodentia, Caviidae). Bioscience Journal, 2015, vol. 31, n. 4, p. 1174- 1182. http://dx.doi.org/10.14393/BJ-v3ln4a2015-26061.

SASSAKI, KT., DELBEM, AB., SANTOS, OAM., SHIMABUCORO, CE., NAKAMUNE, ACMS., BEDRAN-DE-CASTRO, JC. and OLIVEIRA-FILHO, RM. Neuroendocrine alterations impair enamel mineralization, tooth eruption and saliva in rats. Pesquisa Odontologica Brasileira, 2003, vol. 17, n. 1, p. 5-10. http://dx.doi.org/10.1590/ S1517-74912003000100002. PMid:12908052.
SOUZA, AF., OLIVEIRA, VC., SANTOS, AC., ROSA, RA., CARVALHO, AF., AMBRÓSIO, CE. and MANÇANARES, CAF. Morfologia macro e microscópica das papilas linguais do quati (Nasua nasua). Pesquisa Veterinaria Brasileira, 2012, vol. 32, n. 3, p. 271277. http://dx.doi.org/10.1590/S0100-736X2012000300016.

THOMAZ, JM., CARVALHO, AF., MIGLINO, MA., MANÇANARES, CAF., AMBRÓSIO, CE. and OLIVEIRA, MF. Caracterização morfológica dos dentes de Mocó Kerodon rupestres: Mammalia: Rodentia. Brazilian Journal of Veterinary Research and Animal Science, 2006, vol. 43, n. 5, p. 702-707.

TRIBE, CJ. Dental age classes in Marmosa incana and others Didelphoids. Journal of Mammalogy, 1990, vol. 71, n. 4, p. 566-569. http://dx.doi.org/10.2307/1381795.

Received July 12, 2015 Accepted June 22, 2016 